\title{
The Microflora of Fodders Associated with Bovine Respiratory Disease
}

\author{
By J. LACEY \\ Rothamsted Experimental Station, Harpenden, Hertfordshire
}

(Accepted for publication 21 August 1967)

\begin{abstract}
SUMMARY
The microflora of samples of fodder fed to cattle on $4 \mathrm{I}$ farms where some cattle suffered respiratory disease was comparable with the microflora of hays, previously reported. Of the 59 samples of fodder examined, 30 from 29 different farms were very mouldy and were comparable with farmer's-lungtype hay in being rich in Micropolyspora faeni and Thermoactinomyces vulgaris. The remaining samples were classified as either good or mouldy in almost equal numbers.
\end{abstract}

\section{INTRODUCTION}

The disease in man called farmer's lung is caused by inhaling dust from very mouldy hay (Pepys et al. 1963). Such hay is produced when it is baled at water contents from about $35-45 \%$; such bales may heat spontaneously at $50-70^{\circ}$ (Gregory, Lacey, Festenstein \& Skinner, 1963; Festenstein et al. 1965). In these conditions thermophilic and thermotolerant fungi and actinomycetes grow abundantly. These often include Micropolyspora faeni (Thermopolyspora polyspora; see Cross, Maciver \& Lacey, I968), the richest known source of farmer's-lung hay (f.l.h.) antigen, and Thermoactinomyces vulgaris, another source. Large spore concentrations occur in the air of farm buildings when such mouldy hays are moved (Lacey \& Lacey, 1964). Cattle are also subjected to large spore concentrations when feeding on mouldy hay (Austwick, 1963), and actinomycetes have been isolated in large numbers from the lungs of even healthy cattle (Austwick, I966).

Classically, fog fever is a disease of cattle feeding on aftermath pasture (foggage) during autumn in the west of England, but the name has also been applied to clinically similar diseases, also of unknown aetiology, of housed cattle. Jenkins \& Pepys (1965) found precipitins to f.l.h. antigen in the sera of housed cattle said to be affected with fog fever, and in some unaffected cattle. These precipitins resemble those in the sera of farmer's-lung patients, which suggest that respiratory disease in some animals may also be caused by inhaling dust from mouldy hay.

The microflora of fodders sent from farms where cattle had suffered from respiratory disease was examined and compared with that of mouldy hays associated with farmer's-lung disease (Gregory \& Lacey, 1963a). Some fodders were received during a survey organized by the Veterinary Clinical Observation Unit, for which immunological results have been reported (Jenkins \& Pepys, 1965). 


\section{METHODS}

All the samples of fodder were examined by the wind-tunnel method, by using the cascade impactor and Andersen sampler as described by Gregory \& Lacey (1963a), except that grain samples were first put in small muslin bags. Spores blown off the fodders were sampled first with the cascade impactor, operated approximately isokinetically with the wind speed of $4.2 \mathrm{~m}$./ $/ \mathrm{sec}$. for $3 \mathrm{~min}$., and then with the Andersen sampler, operated at $251 . / \mathrm{min}$. for 5 successive runs of $15 \mathrm{sec}$. each with a fresh set of plates. Two of these sets of plates contained $2 \%$ malt agar with penicillin ( 20 units $/ \mathrm{ml}$.) and streptomycin ( 40 units $/ \mathrm{ml}$.), and 3 contained half-strength 'Oxoid' nutrient agar with actidione $\left(0.5 \mathrm{mg} . / \mathrm{ml}\right.$.). Incubation was at $25^{\circ}, 40^{\circ}$ (one set malt agar and one set nutrient agar plates at each temperature) and $60^{\circ}$ (nutrient agar only).

\section{RESULTS}

In all, 59 samples of hay, straw and grain were examined between September 1962 and February 1966; these came from 4I farms where cattle had suffered respiratory disease. These samples are classified according to type and degree of mouldiness (after Gregory \& Lacey, 1963a; Gregory et al. 1963) in Table I. Most of the species recorded by Gregory \& Lacey (1963a) and Gregory et al. (1963) were also isolated from these fodders, with the addition of the following fungi: Aspergillus oryzae, Penicillium piceum, Doratomyces sp., Chaetomium indicum, Dactylomyces crustaceus, Malbranchea pulchella var. sulfurea, Monascus purpureus, Thamnidium elegans, Aspergillus clavatus, A. candidus, Microascus sp., Syncephalastrum racemosum and Thermoascus aurantiacus. The actinomycetes isolated included Thermoactinomyces vulgaris, Micropolyspora faeni, Thermonospora viridis, Streptomyces fradiae, $S$. thermoviolaceus, $S$. griseoflavus.

Table I. Spore content of fodder samples, and occurrence of Micropolyspora faeni and Thermoactinomyces vulgaris

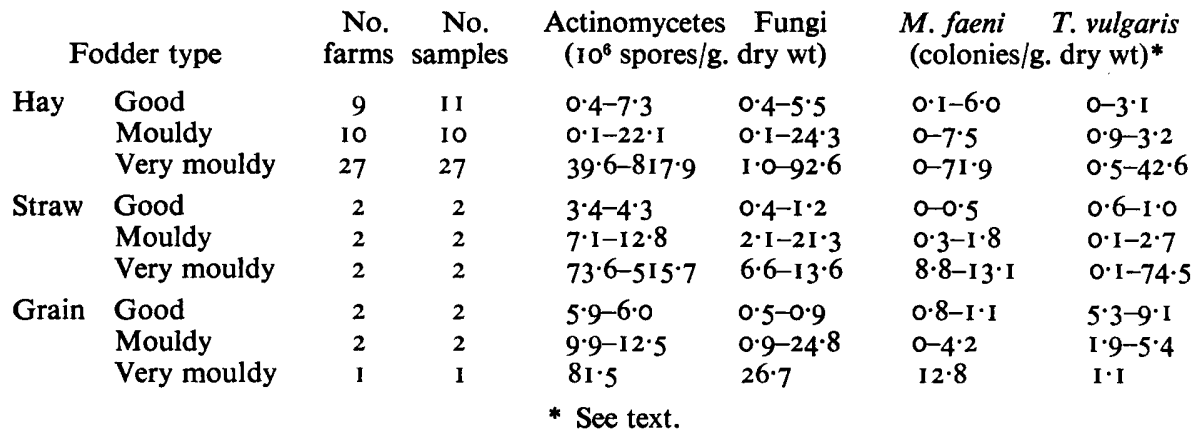

The microflora of the fodder types classified by spore load as good, mouldy and very mouldy agreed approximately with those described by Gregory \& Lacey (1963a), but there were a few exceptions. Micropolyspora faeni and Thermoactinomyces vulgaris were usually abundant in the very mouldy hays, most of which yielded more than 2 colonies of each organism $/ g$. dry wt in a standard Andersen sampler run (equivalent to about $1 \%$ of the blowable, or $0.15 \%$ of the total spore load; Gregory \& Lacey, I963 $b$; Table 2). Thermoactinomyces vulgaris, although more abundant than $M$. faeni in most hays, 
varied more and was very rare in some samples. However $M$. faeni was not isolated from one very mouldy sample, although this contained $112 \times 10^{6}$ actinomycete and $75 \times 10^{6}$ fungal spores/g. dry wt, and was rich in $T$. vulgaris. Good samples of hay yielded fewer than 2 colonies of $M$. faeni/g. dry wt, and only about one third of the samples classified as mouldy had more than this.

Table 2. Occurrence of Micropolyspora faeni and Thermoactinomyces vulgaris in fodder of different types

\begin{tabular}{|c|c|c|c|c|c|c|}
\hline \multirow{3}{*}{ Fodder type } & \multicolumn{6}{|c|}{ No. colonies/g. dry wt sample* } \\
\hline & $0-0.5$ & $0 \cdot 6-2 \cdot 0$ & $2 \cdot 1-5 \cdot 0$ & $5 \cdot I-20 \cdot 0$ & $20 \cdot 1-50 \cdot 0$ & $>50 \cdot 1$ \\
\hline & & \multicolumn{5}{|c|}{ M. faeni $:$ no. samples in each class } \\
\hline Good & 9 & 5 & o & I & $\circ$ & $\circ$ \\
\hline Mouldy & 4 & 5 & 3 & 2 & 0 & $\circ$ \\
\hline \multirow[t]{2}{*}{ Very mouldy } & I & o & 5 & 16 & 5 & 3 \\
\hline & & \multicolumn{5}{|c|}{ T. vulgaris: no. samples in each class } \\
\hline Good & 5 & 4 & 4 & 2 & 0 & o \\
\hline Mouldy & I & 7 & 4 & 2 & o & 0 \\
\hline Very mouldy & 3 & 4 & 2 & IO & 6 & 5 \\
\hline \multicolumn{7}{|c|}{ * See text. } \\
\hline \multicolumn{7}{|c|}{$\begin{array}{l}\text { 3. Relationship between the occurrence of respiratory disease and the } \\
\text { mum number of Micropolyspora faeni isolated from associated fodder }\end{array}$} \\
\hline & \multicolumn{6}{|c|}{ Maximum no. $M$. faeni colonies/g. dry wt sample* } \\
\hline & $0-0.5$ & $0 \cdot 6-2 \cdot 0$ & $2 \cdot 1-5 \cdot 0$ & $5 \cdot 1-20 \cdot 0$ & $20 \cdot 1-50 \cdot 0$ & $>50 \cdot \mathrm{I}$ \\
\hline No. farms: & 6 & 4 & 6 & 17 & 5 & 3 \\
\hline & & ${ }^{*} \mathrm{~S}$ & text. & & & \\
\hline
\end{tabular}

Actinomycetes are not the only organisms in mouldy hay which are able to cause respiratory disease in cattle, and other potential pathogens were isolated, sometimes in large numbers. The most common were Aspergillus fumigatus, A. nidulans, Absidia sp. and Mucor pusillus. Precipitins to A. fumigatus have also been found in cattle sera (Jenkins \& Pepys, 1965).

More than one fodder sample was received from some farms and these were usually of different types. Very mouldy fodders came from 29 farms $(7 \mathrm{I} \%)$ and more than 2 colonies of Micropolyspora faeni/g. dry wt were isolated from at least one sample from 3I farms (76\%; Table 3). One sample was of particular interest since, unlike all the others, it was associated with fog-fever in grazing cattle. Hay had been cut earlier in the year but had not been removed from the pasture. New grass which had grown through was being grazed by the affected cattle. Samples from this old hay did not contain a large number of spores ( $17.7 \times 10^{6}$ actinomycetes, $3.7 \times 10^{6}$ fungi/g. dry wt); but 8.3 colonies of $M$. faeni/g. dry wt were isolated which may have been important.

Immunological tests, with sera from 96 cattle on 23 farms showed that 47 of the cattle on 16 of the farms had precipitins to f.l.h. antigen. (P. A. Jenkins \& J. Pepys, personal communication). 


\section{DISCUSSION}

Although only $5 \mathrm{I} \%$ of the samples from farms where cattle had suffered respiratory disease could be classified as very mouldy, or of farmer's-lung type (after Gregory \& Lacey, I963a), at least one very mouldy sample came from $7 \mathrm{I} \%$ of the farms. At least one sample from another $5 \%$ produced more than 2 colonies of Micropolyspora faenil g. dry wt. The samples from the remaining farms may not have been typical of the fodder being fed before, or at the time of, the outbreak of disease, and so did not reflect the respiratory spore intake of the affected cattle. It has not yet been possible to correlate the results reported here with the clinical and pathological findings in the disease outbreaks at places from which the samples came, but the clinical definition of 'fog-fever' was used as a criterion for the selection of samples. This syndrome is thought to have several causes, of which actinomycete, and possibly mould spores, are only two. The possibility that inhaled spores exacerbate symptoms of concurrent infection by viruses or bacteria must also be considered. However, the presence of precipitins to FLH antigen in sera from the animals suggests a parallel with farmer's-lung disease. This is certainly evidence of exposure to dust from mouldy hay, but is not necessarily proof that this dust caused disease, because precipitins have been found in apparently healthy animals (Jenkins \& Pepys, I965).

Except for the one farm, this survey did not include examples of respiratory disease in grazing animals. Although thermophilic actinomycetes, including Thermoactinomyces vulgaris, have been isolated from soil and grass litter (Cross, 1968; Lacey, unpublished), few spores are probably released from these sources as compared with the numbers from hay, perhaps too few to cause disease. The clinical form of fogfever of cattle grazing aftermath pasture is probably caused by other agents; hypersensitivity to lungworm larvae (Dictyocaulus viviparus) is one suggestion (Michel, 1954).

There is a need for a better definition of fog-fever, and possibly the limitation of this name for the classical disease of animals at pasture. Although there are similarities between respiratory disease of some housed cattle and farmer's-lung disease in man, further work is needed to consider all possible causes, with more detailed immunological work with the cattle and information about the microbiology of their fodder. Inhalation tests with extracts of actinomycetes and fungi isolated from hay are needed to see whether they cause disease in cattle as they do in man, and to assess how important mouldy hay is as a cause of allergic respiratory disease in cattle.

Although most very mouldy hays usually produced more, and other hays fewer, than 2 colonies of Micropolyspora faeni/g. dry wt in standard wind-tunnel tests, this seemingly small figure is probably an underestimate, for the various reasons given by Gregory \& Lacey (I963a), who could grow in culture only $0.1 \%$ of the spores seen on cascade impactor slides. Although a statistical correction can be applied for multiple impaction by the Andersen sampler jets, it is difficult to allow for the number of spores per particle deposited on the upper stages of the Andersen sampler, or for spore viability. However, the viable particles may not be the only ones that can cause respiratory disease, because dead particles may be allergenic.

I thank Dr J. Pepys and Dr P. A. Jenkins (Institute of Diseases of the Chest, Brompton) for giving me the results of their immunological tests, Messrs P. K. C. 
Austwick (Central Veterinary Laboratory, Weybridge) and I. G. Shaw (Veterinary Investigation Centre, Worcester) for samples and valuable discussions, and Messrs A. V. H. G. Abbot (Bodmin), D. T. E. Bowen (Llandeilo), A. M. Brown (Midsomer Norton), D. Campbell (Keighley), G. A. Crawshaw (Newbury), R. B. Fletcher (Glastonbury), J. C. Hindson (Heatherleigh), A. R. Hopkins (Tiverton), F. V. John (Llandeilo), J. Millar (Wigtown), B. F. Tebbutt (St Neots), and W. D. Wildman (Leicester) for samples.

\section{REFERENCES}

Austwick, P. K. C. (1963). Ecology of Aspergillus fumigatus and the pathogenic phycomycetes. Recent Progr. Microbiol. 8, 644.

Austwick, P. K. C. (1966). The role of spores in the allergies and mycoses of man and animals. In The fungus spore, Colston Pap. 18, $32 \mathrm{I}$.

Cross, T. (1968). The thermophilic actinomycetes. J. appl. Bact. 3r, (in the Press).

Cross, T., Maciver. A. M. \& LaceY, J. (1968). The thermophilic actinomycetes of mouldy hay: Micropolyspora faeni nov.sp. J. gen. Microbiol. 50, 35I.

Festenstein, G. N., Lacey, J., Skinner, F. A., Jenkins, P. A. \& Pepys, J. (1965). Self-heating of hay and grain in Dewar flasks and the development of farmer's lung antigens. J. gen. Microbiol. 4r, 389.

Gregory, P. H. \& LACEY, M. E. (1963a). Mycological examination of dust from mouldy hay associated with farmer's lung disease. J. gen. Microbiol. 30, 75 .

Gregory, P. H. \& LACEY, M. E. (1963b). Liberation of spores from mouldy hay. Trans. Br. mycol. Soc. 46,73 .

Gregory, P. H., Lacey, M. E., Festenstein, G. N. \& Skinner, F. A. (1963). Microbial and biochemical changes during the moulding of hay. J. gen. Microbiol. 33, I47.

Jenkins, P. A. \& PePYS, J. (1965). Fog-fever. Precipitin (FLH) reactions to mouldy hay. Vet. Rec. $77,464$.

LACEY, J. \& LACEY, M. E. (1964). Spore concentrations in the air of farm buildings. Trans. Br. mycol. Soc. 47, 547 .

Michel, J. F. (1954). A contribution to the etiology of fog fever. Vet. Rec. 66, 38I.

Pepys, J., Jenkins, P. A., Festenstein, G. N., Gregory, P. H., Lacey, M. E. \& Skinner, F. A. (I963). Farmer's lung: thermophilic actinomycetes as a source of 'farmer's lung hay' antigen. Lancet ii, 607. 